Magdalena Dutsch-Wicherek ${ }^{1,2}$, Magdalena Bańkowska-Woźniak², Wojciech Kazmierczak ${ }^{3}$, Klaudia Cierniak-Kożuch ${ }^{4}$, Konrad Dziobek ${ }^{2}$, Łukasz Wicherek ${ }^{2,5}$

${ }^{1}$ University Children's Hospital of Cracow, Jagiellonian University Medical College, Cracow, Poland

2Oncology Centre in Bydgoszcz, Poland

${ }^{3}$ Department of Sensory Research, Collegium Medicum, Nicolaus Copernicus University, Bydgoszcz, Poland

${ }^{4}$ Department of Otolaryngology, University Children's Hospital of Cracow, Jagiellonian University Medical College, Cracow, Poland

5Department of Oncology, Radiotherapy and Gynaecological Oncology, Collegium Medicum, Nicolaus Copernicus University, Bydgoszcz,

Poland

\title{
The quality of life and the occurrence of dysphagia in patients with head and neck cancer following combined oncological treatment
}

\section{Corresponding author:}

Dr. hab. n. med.

Magdalena Dutsch-Wicherek

Uniwersytet Jagielloński Collegium

Medicum Uniwersytecki Szpital

Dziecieccy

Wielicka 265 St.

30-663, Kraków, Poland

E-mail: mowicher@gmail.com
Medical Research Journal 2017; Volume 2, Number 1, 13-19 10.5603/MRJ.2017.0003 Copyright (C) 2017 Via Medica ISSN 2451-2591

\begin{abstract}
Introduction. The localisation of head and neck carcinomas influences the functions of speech, breathing and swallowing, which, in turn, directly affect the patient's quality of life. The poor prognosis associated with tumours of this type indicates that aggressive combined therapy protocols, including surgery, chemotherapy, and radiotherapy, should be implemented. Such treatments commonly cause acute toxicity and short- and long-term swallowing complications. Therefore, even though they can contribute significantly to survivorship, these treatments reduce the quality of life. The aim of this study was to analyse the influence of applied combined oncological treatments on the occurrence of dysphagia in patients with head and neck cancer and on their quality of life.

Methods. A group of 135 patients with head and neck carcinomas treated with combined protocol (surgery, chemotherapy, and radiotherapy) in the Lukaszczyk Oncological Centre in Bydgoszcz between 2010 and 2014 was analysed. The quality of life and subjective evaluation of the swallowing function was assessed using the MDADI (M.D. Anderson Dysphagia Inventory)

Results. A statistically significantly worse subjective evaluation of the quality of life was observed in the patients with dysphagia, who had undergone surgery with radiotherapy, compared to those who had not had surgery $(p=0.03)$. A statistically significantly worse subjective quality of life evaluation was found in patients who had the most locally advanced tumours (T4) $(p=0.04)$ as well as the highest stages of the disease $(S 3$ and $S 4)(p=0.04)$. A statistically significantly worse subjective quality of life with dysphagia was also seen in patients who had chemoradiotherapy in comparison to those who had radiotherapy alone $(p=0.01)$. A statistically significantly worse subjective quality of life with dysphagia was observed in the patients whose tumours were localised in the oral part of the pharynx and larynx compared to those patients with other tumour localisations $(p=0.02)$. A statistically significantly worse subjective quality of life with dysphagia was identified in the patients who had a higher dose of radiation (exceeding 45 Gy) in the upper oesophageal sphincter compared to those patients who had a lower dose (below 45 Gy) in the UES $(p=0.01)$

Conclusions. In patients with dysphagia, surgical treatment negatively impacts their subjective quality of life. Moreover, the pattern of radiation therapy affects the quality of life in patients with dysphagia. A radiation therapy plan that spares the upper oesophageal sphincter by using a dose of less than $45 \mathrm{~Gy}$ may prevent dysphagia. Dysphagia is also associated with tumour localization, tumour stage, and local advancement of the disease.
\end{abstract}

Key words: dysphagia, combine oncological treatment, MDADI (M.D. Anderson Dysphagia Inventory)

Med Res J 2017; 2 (1): 13-19 


\section{Introduction}

Malignant head and neck tumours are localised within the mucosa of the upper respiratory and gastrointestinal tract (oral cavity, pharynx, larynx, nasal cavity, salivary glands, and paranasal sinuses) and are related to similar diagnostic and therapeutic problems, although these differ along with the natural clinical course of the disease and prognosis [1]. This localisation of tumours significantly affects the most important life functions of speech, breathing, and swallowing, which, in turn, negatively impact the quality of life of the patient. These functions are influenced, on the one hand, by the tumour infiltrating the organs, but, on the other hand, are compromised by the aggressive oncological treatment. Despite modern methods of combined treatment, cases of head and neck cancers are characterised by a poor prognosis; the five-year survival rate is $50 \%$ [2]. Aggressive, combined treatment (radiochemotherapy and surgery) is therefore typically used to improve the therapeutic effect. This treatment, however, is characterised by high toxicity and increases the risk of early and late post-radiation effects, negatively affecting the patient's quality of life [3]. Dysphagia is present at the moment of diagnosis in 2/3 of patients suffering from head and neck cancer. In $1 / 3$ of the patients with dysphagia, aspiration is observed and is complicated by aspiration pneumonia, which, according to various authors, carries a high mortality rate ranging from $20-60 \%$ [3]. The aim of the present analysis has been to evaluate the influence of the applied therapy on the quality of life of patients with head and neck cancer and the occurrence of dysphagia.

\section{Materials and methods}

Patients

We selected 135 patients suffering from head and neck cancer, who were treated with combined therapy (surgery, chemotherapy, and radiotherapy) in the Oncological Centre in Bydgoszcz between 2010 and 2014 , in order to evaluate their quality of life and dysphagia. Table 1 presents the clinical characteristics of the patients. Table 2 presents the morphological

Table 1. Characteristics of patients

\begin{tabular}{lcc}
\hline & Women & Men \\
\hline Av. Age (years) & 58.13 & 58.54 \\
Smoking & $27 \%$ & $39 \%$ \\
Alcohol & $5 \%$ & $17 \%$ \\
\hline
\end{tabular}

Table 2. Morphological characteristics of tumours

\begin{tabular}{|c|c|c|}
\hline & Number of patients & $\%$ \\
\hline T1 & 15 & $11 \%$ \\
\hline T2 & 48 & $35 \%$ \\
\hline T3 & 48 & $35 \%$ \\
\hline T4 & 22 & $16 \%$ \\
\hline TX & 2 & $1 \%$ \\
\hline $\mathrm{N}+$ & 76 & $57 \%$ \\
\hline N1 & 14 & $10 \%$ \\
\hline $\mathrm{N} 2 \mathrm{a}$ & 9 & $6 \%$ \\
\hline $\mathrm{N} 2 \mathrm{~b}$ & 29 & $21 \%$ \\
\hline $\mathrm{N} 2 \mathrm{C}$ & 22 & $16 \%$ \\
\hline N3 & 2 & $1 \%$ \\
\hline $\mathrm{N}-$ & 59 & $43 \%$ \\
\hline$M+$ & 0 & 0 \\
\hline M- & 135 & $100 \%$ \\
\hline SI & 13 & $10 \%$ \\
\hline SII & 26 & $19 \%$ \\
\hline SIII & 30 & $23 \%$ \\
\hline SIVa & 58 & $43 \%$ \\
\hline SIVb & 7 & $5 \%$ \\
\hline SIVc & 1 & $0.01 \%$ \\
\hline Squamous cell carcinoma & 135 & $100 \%$ \\
\hline
\end{tabular}

$\mathrm{T}$ - tumour size; $\mathrm{N}$ - the presence of lymph node metastases;

$\mathrm{M}$ - the presence of metastases; $\mathrm{S}$ - stage of disease (SI-SIVc)

Table 3. Tumour localisation

\begin{tabular}{lc}
\hline Tumour localisation & $\begin{array}{c}\text { Number of patients } \\
\text { (n = 135) }\end{array}$ \\
\hline Oral cavity & 21 \\
Oropharynx & 38 \\
Hypopharynx & 12 \\
Larynx & 49 \\
$\begin{array}{l}\text { Tumours infiltrating more than one } \\
\text { organ (oral cavity and oropharynx. } \\
\text { hypopharynx and larynx) }\end{array}$ & 15 \\
\hline
\end{tabular}

characteristics of the tumours. Table 3 presents the localisation of the tumours, and Table 4 shows the type of treatment applied.

A subjective evaluation of the quality of life and dysphagia in patients following the combined oncological treatment was performed using the Polish translation of the MDADI (M.D. Anderson Dysphagia Inventory) [4]. The MDADI questionnaire includes four groups of questions characterising the factors influencing patient quality of life: 
Table 4. Characteristics of the treatment

\begin{tabular}{lc}
\hline Treatment & Number of patients $(\mathbf{n}=\mathbf{1 3 5})$ \\
\hline Planning radiotherapy with PET-CT & $51(38 \%)$ \\
Radiotherapy & $16(12 \%)$ \\
Chemo-radiotherapy & $31(23 \%)$ \\
Radiotherapy/chemo-radiotherapy+ surgical treatment & $88(65 \%)$ \\
\hline
\end{tabular}

Table 5. Subjective evaluation of dysphagia in patients with respect to the applied treatment

\begin{tabular}{lcc}
\hline Questions & Surgical treatment & No surgical treatment \\
\hline $1-$ global assessment of swallowing difficulty & NS & NS \\
$2-$ emotional disorders correlated with dysphagia & $p=0.0376$ & NS \\
$3-$ family and social dysfunction related to dysphagia & $p=0.3604$ & NS \\
$4-$ functional effects of dysphagia & NS & NS
\end{tabular}

NS - no statistical significance

- the first group of questions: the global assessment of swallowing difficulty (question 1);

- the second group of questions concerns the emotional disorders correlated with dysphagia (questions: $2,5,6,12,18)$

- the third group of questions concerns family and social dysfunction related to dysphagia (questions: $3,9,14,15,20)$;

- the fourth group of questions concerns the functional effects of dysphagia (questions: 4, 7, 10, 11, $13,16,17,19)$.

Out of five possible answer choices, only one could be selected: 1- strongly agree, 2 -agree, 3 - no opinion, 4 - disagree, 5 - strongly disagree. The items were scored, and the mean score was multiplied by 20 to obtain a score with the range from 0 (extremely low functioning) to 100 (high functioning) $[5,6]$.

Approval for the research program was granted by the Ethical Committee of the Nicolaus Copernicus University in Torun, Medical College in Bydgoszcz (KB365/2013). All the patients included in the program agreed to participate in the analysis.

\section{Statistical analysis}

The statistical evaluation was performed using the Statistica 8.0 program (StatSoft, Inc., USA).

The statistical significance between the groups was determined by the Kruskal-Wallis test, one-way analysis of variance by ranks. The Mann-Whitney $U$ test was then used as applicable. All statistical analyses were carried out with Statistica 8.0 software (StatSoft Inc, Tulsa, OK, USA). A p value $<0.05$ was considered to be of statistical significance [7-11].

\section{Results}

A statistically significantly worse subjective evaluation of the quality of life, including emotional disorders (group 2) ( $p=0.03$ ) and family and social dysfunction (group 3$)(p=0.03)$, was observed in the patients who underwent surgical therapy combined with radiotherapy, compared to patients who underwent radiotherapy without surgery. Table 5 presents the results.

A statistically significantly worse subjective evaluation of the quality of life (global assessment of swallowing difficulty) (group 1) was observed in the patients with the greatest local tumour size (T4) compared to patients with smaller tumour size (T1, T2, and T3) $(p=0.04)$. Similarly, a statistically significantly worse subjective quality of life with functional disorders (group 4) was observed in the patients with the greatest tumour size (T4) $(p=0.04)$. Table 6 presents the results.

A statistically significantly worse subjective evaluation of the quality of life with global assessment of swallowing difficulty (group 1) was observed in the patients with higher stages of the disease (stage 3 and 4 , $p=0.04)$. Table 7 presents the results.

A statistically significantly worse subjective quality of life with functional disorders (group 4) was observed in the patients who underwent chemoradiotherapy compared to those patients who underwent only radiotherapy $(p=0.01)$. Table 8 presents the results.

A statistically significantly worse subjective evaluation of the quality of life with functional disorders (group 4) was observed in patients whose tumour localisations included the oropharynx $(p=0.027)$ and larynx $(p=0.02)$ when compared to other tumour localisations. Table 9 presents the results. 
Table 6. Subjective evaluation of swallowing difficulty with respect to tumour size

\begin{tabular}{lcccc}
\hline Questions group & T1 & T2 & T3 & T4 \\
\hline 1 & NS & NS & NS & p $=0.0480$ \\
2 & NS & NS & NS & NS \\
3 & NS & NS & NS & NS \\
4 & NS & NS & NS & 0.0477 \\
\hline
\end{tabular}

NS - no statistical significance; questions group: group 1 - the global assessment of swallowing difficulty; group 2 - emotional disorders correlated with dysphagia; group 3 - family and social dysfunction related to dysphagia; group 4 - functional effects of dysphagia

Table 7. Subjective assessment of dysphagia with respect to the tumour stage

\begin{tabular}{lcccc}
\hline Group of questions & Stage 1 & Stage 2 & Stage 3 & Stage 4 \\
\hline 1 & NS & NS & $p=0.040$ & $p=0.0478$ \\
2 & NS & NS & NS & NS \\
3 & NS & NS & NS & NS \\
4 & NS & NS & NS & NS \\
\hline
\end{tabular}

NS - no statistical significance; questions group: group 1 - the global assessment of swallowing difficulty; group 2 - emotional disorders correlated with dysphagia; group 3 - family and social dysfunction related to dysphagia; group 4 - functional effects of dysphagia

Table 8. Subjective assessment of dysphagia with respect to the applied treatment

\begin{tabular}{lcc}
\hline Group of questions & Patients after radiotherapy & Patients after chemoradiotherapy \\
\hline 1 & NS & NS \\
2 & NS & NS \\
3 & NS & NS \\
4 & NS & $\mathrm{p}=0.0128$
\end{tabular}

NS - no statistical significance; questions group: group 1 - the global assessment of swallowing difficulty; group 2 - emotional disorders correlated with dysphagia; group 3 - family and social dysfunction related to dysphagia; group 4 - functional effects of dysphagia

Table 9. Subjective evaluation of dysphagia with respect to tumour localisation

\begin{tabular}{lcccc}
\hline Group of questions & $\begin{array}{c}\text { Tumour localisation } \\
- \text { oropharynx }\end{array}$ & $\begin{array}{c}\text { Tumour localisation } \\
- \text { hypopharynx }\end{array}$ & $\begin{array}{c}\text { Tumour localisation } \\
\text { - larynx }\end{array}$ & Other localisation \\
\hline 1 & NS & NS & NS & NS \\
2 & NS & NS & NS & NS \\
3 & NS & NS & NS & NS \\
4 & $\mathrm{p}=0.0277$ & NS & $\mathrm{p}=0.0218$ & NS \\
\hline
\end{tabular}

NS - no statistical significance; questions group: group 1 - the global assessment of swallowing difficulty; group 2 - emotional disorders correlated with dysphagia; group 3 - family and social dysfunction related to dysphagia; group 4 - functional effects of dysphagia

A statistically significantly worse subjective evaluation of the quality of life with global assessment of swallowing difficulty (group 1) was observed in the patients in whom the median dose within the upper pharyngeal constrictor (identified as a critical structure) exceeded 45 Gy compared to those patients in whom the dose was lower $(p=0.01)$. Table 10 presents the results.

No statistically significant differences were identified in the analysed groups of patients in relation to the sex, age, the presence of lymph node metastases $(\mathrm{N}+)$, tu- mour grading, and local tumour progression. Table 11 presents the results.

\section{Discussion}

In the present study, a statistically significantly worse individual evaluation of the quality of life was observed in the global assessment of swallowing difficulty and family and social dysfunction in the patients with the 
Table 10. Subjective evaluation of dysphagia with respect to the dose of radiotherapy applied to pharyngeal constrictors

\begin{tabular}{lcc}
\hline Group of questions & $\begin{array}{c}\text { Radiotherapy dose in pharyngeal } \\
\text { constrictors exceeding 45 Gy }\end{array}$ & $\begin{array}{c}\text { Radiotherapy dose in pharyngeal } \\
\text { constrictors not exceeding 45 Gy }\end{array}$ \\
\hline 1 & $\mathrm{p}=0.0118$ & $\mathrm{NS}$ \\
2 & $\mathrm{NS}$ & $\mathrm{NS}$ \\
3 & $\mathrm{NS}$ & $\mathrm{NS}$ \\
4 & $\mathrm{NS}$ & $\mathrm{NS}$ \\
\hline
\end{tabular}

NS - no statistical significance; questions group: group 1 - the global assessment of swallowing difficulty; group 2 - emotional disorders correlated with dysphagia; group 3 - family and social dysfunction related to dysphagia; group 4 - functional effects of dysphagia

Table 11. Subjective assessment of dysphagia with respect to sex, age, the presence of lymph node metastases, tumour grade, and local tumour progression

\begin{tabular}{lllllllc}
\hline $\begin{array}{l}\text { Group of } \\
\text { questions }\end{array}$ & Age & Sex & N+ & G1 & G2 & G3 & $\begin{array}{c}\text { Local tumour } \\
\text { progression }\end{array}$ \\
\hline 1 & NS & NS & NS & NS & NS & NS & NS \\
2 & NS & NS & NS & NS & NS & NS & NS \\
3 & NS & NS & NS & NS & NS & NS & NS \\
4 & NS & NS & NS & NS & NS & NS & NS \\
\hline
\end{tabular}

NS - no statistical significance; questions group: group 1 - the global assessment of swallowing difficulty; group 2 - emotional disorders correlated with dysphagia; group 3 - family and social dysfunction related to dysphagia; group 4 - functional effects of dysphagia

greatest tumour size (T4). A similarly statistically significantly worse individual evaluation of global assessment of swallowing difficulty was observed in the patients whose tumours were in the highest stages (stages 3 and 4). The obtained results remain in accord with the observations of other authors who confirmed that local tumour advancement affects the primary function of the organ and the adjacent tissues, which disturbs the swallowing process before, during, and after the completion of treatment [12]. Eisbruch et al. stated that the most important factors predicting severe dysphagia include tumour size (T3/T4), extra glottic tumour localisation, and hyperfractionation of the radiation dose [13].

In the present study, a statistically significantly worse individual evaluation of the quality of life with functional effects of dysphagia (group 4) was found in patients who had tumours localised in the oropharynx and larynx compared to other localisations. Strek et al. had similar observations [4-5]. The severest dysphagia was identified in patients in whom the tumour was localised in the oral cavity, oropharynx, and larynx with involvement of the epiglottis. These tumour localisations constitute the worst prognostic factors in cases of dysphagia. Eisbruch et.al. described the basic structures for the process of swallowing and aspiration, destruction of which during the treatment procedures leads to dysphagia. These structures include pharyngeal constrictors, glottis, and supraglottic larynx [13]. It would seem, therefore, that the most important predictive factor of dysphagia is the tumour localisation. Our results confirm this observation.
A statistically significantly worse individual quality of life with emotional disorders and family and social dysfunction was observed in the patients who underwent surgical treatment with radiotherapy compared to those patients who underwent radiotherapy alone. The surgical treatment itself affects the function of the resected organ; additionally, the post-surgical wound healing process induces fibrosis, which also compromises proper organ functions. Additional treatment, such as radiotherapy and chemotherapy, escalates the swallowing problems by inducing the acute and late radiation reaction stimulating fibrosis in the subcutaneous tissue and muscles of the irradiated area. In our study, significant deterioration of the quality of life in these patients was observed. The results obtained by using the MDADI questionnaire for all patients undergoing surgical treatment, regardless of the type of surgery, are in accord with other study results demonstrating a diminished quality of life $[4,5]$.

A statistically significantly worse individual quality of life in the functional effects of dysphagia (group 4) was observed in patients who had radiochemotherapy compared to patients who underwent radiotherapy alone. Although radiochemotherapy increases the local tumour control and improves the survival rate while preserving the organ, it is characterised by higher toxicity than radiotherapy $[14,15]$. The incidence of complications following treatment in patients in WHO stages 3 and 4 increases from $14 \%$ following radiotherapy alone to $43 \%$ following chemoradiotherapy [16]. The most common chemotherapies applied in patients with head and neck 
cancer are antimetabolites, taxanes, platinum-based chemotherapy, and carboplatin. Antimetabolites such as methotrexate and 5-fluorouracil seem to have the strongest impact on the development of mucositis; taxanes are commonly related to allergic reactions and peripheral neurotoxicity, while platinum-based antineoplastic chemotherapy induces a strong haematological toxicity $[16,17]$. Simultaneous chemotherapy was the strongest factor correlating with an acute morbidity rate in various studies [16-18]. The combination of chemotherapy with radiotherapy reduces the critical dose of radiotherapy for the swallowing process, which seems to be related to the acute radiotherapy reaction and its consequences for the pharyngeal and laryngeal mucosa [19]. In a randomised trial RTOG 91-11 the strong $\mathrm{mu}$ cositis of the oral cavity and dysphagia increased with the chemotherapy doses compared to the radiotherapy doses, from $24 \%$ and $19 \%$ (radiotherapy alone) to $43 \%$ and $35 \%$ (simultaneous chemoradiotherapy) [20]. Despite this, the survival rate was significantly better in patients following chemoradiotherapy (72 months) than in patients following radiotherapy alone (32 months). The Kaplan-Meyer analysis puts the overall five-year survival rate at $40 \%$ for the group of patients following radiotherapy and at $53 \%$ for the patients following chemoradiotherapy [21].

In the present study, a statistically significantly worse global assessment of swallowing difficulty (group 1) was identified in patients for whom the maximum dose of radiotherapy in the pharyngeal constrictors exceeded 60Gy in comparison to patients for whom the dose did not exceed 45 Gy (in these patients the upper pharyngeal sphincter was considered a critical structure) $(p=0.049)$. Levendag et al. have noticed a correlation between dysphagia and increasing the dose of radiotherapy applied in the upper and medial pharyngeal constrictors: $19 \%$ greater likelihood for every $10 \mathrm{~Gy}$ once the $55 \mathrm{~Gy}$ dose is exceeded. The volume of the structures responsible for swallowing was the prognostic factor [22]. It was therefore confirmed that the core element that determines the quality of life in patients with dysphagia is the type of treatment applied, including the type of surgery, the use of chemotherapy, the general dose of radiotherapy, and the dose applied within the pharyngeal constrictors. In the TransTasman Radiation Oncology Group (TROG) 91.01 study the volume of irradiated pharyngeal tissues (including the mucosa and sphincter muscles) correlated with the risk of enteral nutrition [23]. Deantonio et al. demonstrated that the medium dose for the upper and medial pharyngeal constrictors statistically significantly correlated with the degree of dysphagia [24]. Larson has likewise observed correlations between the dose of radiotherapy and complications following radiotherapy [25]. The evaluation of severe dysphagia as a late complication of radiotherapy in patients surviving longer than five years was performed by Hutcheson et al. The total dose of radiotherapy impacted the occurrence of late dysphagia; it was observed more frequently in patients with a total dose of 70 Gy or higher [26]. Many authors have observed positive effects from proactive swallowing therapy, which were observed not just following the treatment but also 3-6 months after the completion of chemoradiotherapy and 9-12 months after treatment [27-32].

\section{Conclusions}

The type of oncological treatment (surgery, chemotherapy, and the dose of radiotherapy) affects the process of swallowing and can influence the occurrence of dysphagia. The dose of radiotherapy in the upper pharyngeal constrictors determines the type and severity of the swallowing problem and must be considered a critical structure when planning radiotherapy. The occurrence of dysphagia is related to both tumour localisation and the advancement of the disease.

\section{References}

1. Kawecki A. Nowotwory narządów głowy i szyi. In: Mender J. ed. Aktualne zasady postępowania diagnostyczno-terapeutycznego w onkologii. Centrum Medyczne Kształcenia Podyplomowego, Warszawa 2011: 5-20

2. Didkowska J, Wojciechowska U, Zatoński W. Nowotwory złośliwe w Polsce w 2011 roku. Krajowy Rejestr Nowotworów. Warszawa.

3. Russi EG, Corvò R, Merlotti A, et al. Swallowing dysfunction in head and neck cancer patients treated by radiotherapy: review and recommendations of the supportive task group of the Italian Association of Radiation Oncology. Cancer Treat Rev. 2012; 38(8): 1033-1049, doi: 10.1016/j.ctrv.2012.04.002, indexed in Pubmed: 22542950.

4. Stręk P, Gawlik J, Składzień J, et al. Ankietowa samoocena zaburzeń połykania i jakości życia u chorych leczonych z powodu nowotworów głowy i szyi. Otorynolaryngologia. 2003; 3: 120-125.

5. Stręk P, Hydzik-Sobocińska K, Składzień J, et al. Jakość życia a dysfagia u chorych po operacji raka krtani. Otorynolaryngologia. 2005; 4: $142-146$

6. Chen AY, Frankowski R, Bishop-Leone J, et al. The development and validation of a dysphagia-specific quality-of-life questionnaire for patients with head and neck cancer: the M. D. Anderson dysphagia inventory. Arch Otolaryngol Head Neck Surg. 2001; 127(7): 870-876, indexed in Pubmed: 11448365

7. Łomnicki A. Wprowadzenie do statystyki dla przyrodników. Wydawnictwo Naukowe PWN, Warszawa 2010: 141-177.

8. Petrie A, Sabin C. Statystyka medyczna w zarysie. Wydawnictwo Lekarskie PZWL, Warszawa 2006: 51-71.

9. Watała C. Biostatystyka - wykorzystanie metod statystycznych w pracy badawczej w naukach biomedycznych. Alfa Medica Press, Bielsko-Biała 2002: 64-86, 142-154-154.

10. Stanisz A. Biostatystyka. Wydawnictwo Uniwersytetu Jagiellońskiego, Kraków 2005: 135-178.

11. Piłatowska M. Repetytorium ze statystyki. Wydawnictwo Naukowe PWN, Warszawa 2006: 52-55.

12. Locher JL, Bonner JA, Carroll WR, et al. Patterns of prophylactic gastrostomy tube placement in head and neck cancer patients: a consideration of the significance of social support and practice variation. Laryngoscope. 2013; 123(8): 1918-1925, doi: 10.1002/lary.24022, indexed in Pubmed: 23401235

13. Eisbruch A, Schwartz M, Rasch C, et al. Dysphagia and aspiration after chemoradiotherapy for head-and-neck cancer: which anatomic struc- 
tures are affected and can they be spared by IMRT? Int J Radiat Onco Biol Phys. 2004; 60(5): 1425-1439, doi: 10.1016/j.ijrobp.2004.05.050, indexed in Pubmed: 15590174.

14. Russi EG, Corvò R, Merlotti $A$, et al. Swallowing dysfunction in head and neck cancer patients treated by radiotherapy: review and recommendations of the supportive task group of the Italian Association of Radiation Oncology. Cancer Treat Rev. 2012; 38(8): 1033-1049, doi: 10.1016/j.ctrv.2012.04.002, indexed in Pubmed: 22542950.

15. Feng FY, Kim HM, Lyden TH, et al. Intensity-modulated chemoradiotherapy aiming to reduce dysphagia in patients with oropharyngeal cancer: clinical and functional results. J Clin Oncol. 2010; 28(16): 2732-2738, doi: 10.1200/JCO.2009.24.6199, indexed in Pubmed: 20421546.

16. Brizel D. Radiotherapy and concurrent chemotherapy for the treatment of locally advanced head and neck squamous cell carcinoma. Seminars in Radiation Oncology. 1998; 8(4): 237-246, doi: 10.1016/s10534296(98)80021-0

17. Manikantan K, Khode S, Sayed SI, et al. Dysphagia in head and neck cancer. Cancer Treat Rev. 2009; 35(8): 724-732, doi: 10.1016/j. ctrv.2009.08.008, indexed in Pubmed: 19751966

18. Murphy BA, Gilbert J. Dysphagia in head and neck cancer patients treated with radiation: assessment, sequelae, and rehabilitation. Semin Radiat Oncol. 2009; 19(1): 35-42, doi: 10.1016/j.semradonc.2008.09.007, indexed in Pubmed: 19028344.

19. Rütten H, Pop LAM, Janssens GO, et al. Long-term outcome and morbidity after treatment with accelerated radiotherapy and weekly cisplatin for locally advanced head-and-neck cancer: results of a multidisciplinary late morbidity clinic. Int J Radiat Oncol Biol Phys. 2011; 81(4): 923-929, doi: 10.1016/j.jijrobp.2010.07.013, indexed in Pubmed: 21095074.

20. Forastiere AA, Goepfert H, Maor M, et al. Concurrent chemotherapy and radiotherapy for organ preservation in advanced laryngeal cancer. N Engl J Med. 2003; 349(22): 2091-2098, doi: 10.1056/NEJMoa031317, indexed in Pubmed: 14645636.

21. Bernier J, Domenge C, Ozsahin M, et al. Postoperative Irradiation with or without Concomitant Chemotherapy for Locally Advanced Head and Neck Cancer. New England Journal of Medicine. 2004; 350(19): 1945-1952, doi: 10.1056/nejmoa032641.

22. Levendag PC, Teguh DN, Voet $P$, et al. Dysphagia disorders in patients with cancer of the oropharynx are significantly affected by the radiation therapy dose to the superior and middle constrictor muscle: a dose-effect relationship. Radiother Oncol. 2007; 85(1): 64-73, doi: 10.1016/j. radonc.2007.07.009, indexed in Pubmed: 17714815.

23. Poulsen MG, Riddle B, Keller J, et al. Predictors of acute grade 4 swallowing toxicity in patients with stages III and IV squamous carcinoma of the head and neck treated with radiotherapy alone. Radiother Oncol. 2008; 87(2): 253-259, doi: 10.1016/j.radonc.2008.03.010, indexed in Pubmed: 18410976

24. Deantonio L, Masini L, Brambilla M, et al. Dysphagia after definitive radiotherapy for head and neck cancer. Correlation of dose-volume parameters of the pharyngeal constrictor muscles. Strahlenther Onkol. 2013; 189(3): 230-236, doi: 10.1007/s00066-012-0288-8, indexed in Pubmed: 23319255

25. Larson DL, Lindberg RD, Lane $\mathrm{E}$, et al. Major complications of radiotherapy in cancer of the oral cavity and oropharynx. A 10 year retrospective study. Am J Surg. 1983; 146(4): 531-536, indexed in Pubmed: 6625100

26. Hutcheson KA, Lewin JS, Barringer DA, et al. Late dysphagia after radiotherapy-based treatment of head and neck cancer. Cancer. 2012; 118(23): 5793-5799, doi: 10.1002/cncr.27631, indexed in Pubmed: 23640737

27. Kulbersh BD, Rosenthal EL, McGrew BM, et al. Pretreatment, preoperative swallowing exercises may improve dysphagia quality of life. Laryngoscope. 2006; 116(6): 883-886, doi: 10.1097/01 mlg.0000217278.96901.fc, indexed in Pubmed: 16735913.

28. Shune SE, Karnell LH, Karnell MP, et al. Association between severity of dysphagia and survival in patients with head and neck cancer. Head Neck. 2012; 34(6): 776-784, doi: 10.1002/hed.21819, indexed in Pubmed: 22127835

29. Cartmill B, Cornwell P, Ward E, et al. A prospective investigation of swallowing, nutrition, and patient-rated functional impact following altered fractionation radiotherapy with concomitant boost for oropharyngea cancer. Dysphagia. 2012; 27(1): 32-45, doi: 10.1007/s00455-011 9333-5, indexed in Pubmed: 21344190.

30. van der Molen L, van Rossum MA, Burkhead LM, et al. Functiona outcomes and rehabilitation strategies in patients treated with chemoradiotherapy for advanced head and neck cancer: a systematic review. Eur Arch Otorhinolaryngol. 2009; 266(6): 889-900 doi: 10.1007/s00405-008-0817-3, indexed in Pubmed: 18825400

31. van der Molen L, van Rossum MA, Burkhead LM, et al. A randomized preventive rehabilitation trial in advanced head and neck cancer patients treated with chemoradiotherapy: feasibility, compliance, and short-term effects. Dysphagia. 2011; 26(2) 155-170, doi: 10.1007/s00455-010-9288-y, indexed in Pubmed: 20623305.

32. Shinn EH, Basen-Engquist K, Baum G, et al. Adherence to preventive exercises and self-reported swallowing outcomes in post-radiation head and neck cancer patients. Head Neck. 2013; 35(12): 1707-1712, doi: 10.1002/hed.23255, indexed in Pubmed: 24142523. 